\title{
Memories of Past Presidents
}

\author{
Prepared by Denise L. Rode
}

Six of NODA's past presidents shared their thoughts about NODA's history in a recent leadership survey compiled by Maria Sedotti of the University of Connecticut. Their responses help to convey a sense of how NODA developed over the past 30 years into a strong association which serves the diverse needs of students and orientation practitioners. The presidents responding identified professional leadership opportunities, travel to annual conferences, life-long friendships, and encouragement from colleagues as the rewards of their NODA involvement. We thank them, and those who preceded and followed them, for their contributions to building the foundation of NODA.

\section{David Hansen (President, 1984-1986)}

Associate Vice President emeritus and Special Assistant to the Vice President for Student Services at the University of Nevada, Reno

During Dave's tenure, NODA regions were reorganized and the first Director of Regions position was discussed. NODA's publications (the Journal and the Orientation Review) were struggling; the Review was revitalized. This was a time of great collaboration with other professional associations, including NASPA, ACPA, NACADA, and the First-Year Experience movement. Dave remembers his first conference in 1976 at the University of Tennessee as well as the 10th anniversary celebration in Fort Worth in 1986. Reflecting on NODA's early years, he warmly recalls working with young professionals, the NODA leadership team, and the "very talented" Board of Directors.

\section{Jim Zakely (President, 1988-1990)}

\section{Health Professions Adviser, Colorado State University}

Under Jim's tenure as President, CAS (Council for the Advancement of Standards in Higher Education) Standards for Orientation were developed and approved. NODA also grew from three regions to nine, and restructured the Board of Directors membership to be apportioned by regions rather than by other criteria (i.e., institutional size or type). The association also created the position of Director of Regions and developed a policy for exhibitors and vendors at national conferences. A membership survey also was disseminated. Zakely's presidency coincided with the growth of the First-Year Experience movement. He fondly recalls being part of the association while several of NODA's founders (the Steering Committee of 1976) were still active, and he was able to hear the history of NODA 
first-hand.

Zakely notes that orientation conferences have occurred since 1948 and that the vote to form an association was taken in 1976, although NODA was not officially incorporated until 1977. NODA's first Board of Directors (formerly the steering committee) considered 1976 to be the founding year of the Association, although NODA has elected to celebrate its 30th year in 2007.

\section{Richard Mullendore (President, 1990-1992)}

Professor of College Student Affairs Administration, Coordinator of the CSAA doctoral program at the University of Georgia and Senior Fellow with the National Resource Center for The First-Year Experience and Students in Transition

Dick recalls the Board of Directors grappling with financial losses after the 1991 conference, expanding NODA awards beyond scholarships and publication awards, and taking the risk of collaborating on its first monograph with the Center for The First-Year Experience and Students in Transition (a project Mullendore co-edited). The monograph and first parent guide (another joint project) helped NODA establish a scholarly reputation and achieve financial stability.

Issues for orientation during his term of office included the timing of orientation (summer vs. fall), separating parents from students during orientation programs, the impact of orientation on retention, and the compensation of orientation leaders. Looking back, he commends NODA for its strategic planning, which has led to the establishment of a home office and paid staff.

\section{Becky Smith (President, 1992-1994)}

Director of Alumni Relations at Otterbein College (OH)

"Hot topics" during her time as president included transfer and parent orientation programs, first-year experience, and the relationship of Orientation to academic affairs units. NODA issues during her presidency were strategic planning for the organization, discussion of a home office, publishing a monograph, and establishing financial stability. Becky fondly remembers some outstanding conference keynote speakers, undergraduate and graduate student involvement at conferences, and serving as an OPI (Orientation Professionals Institute) faculty member.

\section{Victor Wilson (President, 1994-1996)}

Senior Vice President for Student Affairs at the College of Charleston (SC) and NODA OPI faculty member

During Wilson's term as president, the topics of parent programming, funding for Orientation, and staff training were salient for the profession. The association 
also dealt with conference cost affordability, developing NODAnet, and creating the Director of Membership Services position. Among Victor's memories are "Looking at that orange and blue banner each year at the [conference] opening banquet and seeing how many conferences we have had in the past and where each one was held. I always look forward to. . .this reminder of our history."

\section{Jeanine Ward-Roof (President, 1998-2000)}

Dean of Students at Florida State University

Parents, technology, accountability, resources, and connections with academic departments were important topics during Jeanine's presidency. She also points to Orientation's link to retention as a debated issue at that time. Jeanine's most enjoyable NODA memories have been collegial relationships at conferences, learning about new aspects of the field, and board involvement. In addition to serving as president, Jeanine has co-edited a monograph and the Orientation Review, has hosted an annual conference, has been on the OPI faculty, and was Director of Regions. 